\title{
IMPLEMENTASI PERENCANAAN ASUHAN KEPERAWATAN DI RUMAH SAKIT
}

\section{Fara Diba Salsabila Harahap}

\section{Email : salsabilaharahapfaradiba@gmail.com}

\section{Latar Belakang}

Kualitas pelayanan keperawatan di rumah sakit tidak akan berjalan dengan baik apabila proses keperawatan yang dilaksanakan tidak terstruktur dengan baik. Pelaksanakan asuhan keperawatan dengan menggunakan metode proses keperawatan untuk menyelesaikan masalah pasien, antara pasien dan perawat berhubungan secara langsung dalam pengelolaan asuhan keperawatan (Muhlisin, 2008).

Perawat profesional dihadapkan pada suatu tuntutan tanggung jawab yang lebih tinggi dan tanggung gugat setiap tindakan yang dilaksanakan, artinya intervensi keperawatan yang diberikan kepada klien harus dihindari terjadinya kesalahankesalahan dengan pendekatan proses keperawatan dan pendokumentasian asuhan keperawatan yang akurat dan benar (Nursalam 2009).

Dokumentasi keperawatan menjadi salah satu fungsi yang paling penting dari perawat sejak zaman Florence Nightingale, sistem pelayanan kesehatan mengharuskan adanya pendokumentasian karena dapat menjamin kelangsungan perawatan, dapat berfungsi sebagai bukti hukum dari proses perawatan dan mendukung evaluasi kualitas perawatan pasien, perawat yang kurang patuh dalam pendokumentasi asuhan keperawatan akan berakibat pada rendahnya mutu kelengkapan dokumentasi asuhan keperawatan. Semakin baik dalam pengisian dokumentasi keperawatan akan membuat perencanaan keperawatan menjadi lebih baik dan kepuasan pasien meningkat. (AlAssaf,2009).

Asuhan keperawatan adalah suatu pendekatan untuk pemecahan masalah pada pasien dengan memberikan pelayanan keperawatan. Rencana keperawatan merupakan metode komunikasi tentang asuhan keperawatan kepada pasien (Aziz, 2002). Setiap pasien yang memerlukan asuhan keperawatan perlu suatu perencanaan yang baik. Asuhan keperawatan yang rendah menyebabkan mutu pelayanan keperawatan juga menurun dan akhirnya memicu ketidakpuasan pasien, hal yang demikian akan terus menerus berulang jika tidak segera diatasi.

Perencanaan adalah bagian dari fase pengorganisasian dalam proses keperawatan yang meliputi tujuan perawatan, penetapan pemecahan masalah, dan menentukan tujuan perencanaan untuk mengatasi masalah klien (Aziz, 2002). Suatu perencanaan yang kurang baik akan berakibat rendahnya mutu pelayanan keperawatan pada pasien sebagai akibat dari data yang kurang lengkap.

Rumah sakit sebagai salah satu bentuk organisasi pelayanan kesehatan yang memberikan pelayanan kesehatan yang komprehensif mencakup aspek promotif, preventif, kuratif dan rehabilitatif bagi seluruh lapisan masyarakat, sering kali mengalami permasalahan yang menyangkut 
tentang ketidakpuasan masyarakat terhadap mutu pelayanan rumah sakit yang dianggap kurang memadai atau memuaskan.

\section{Metode}

Metode yang digunakan dalam penulisan ini yaitu menggunakan literature riview atau studi pustaka berdasarkan teks book, jurnal dan berfokus pada Implementasi Perencanaan Asuhan Keperawatan di Rumah Sakit. Dengan cara menganalisis, eksplorasi sumber dan kajian bebas. Adapun sumber kajian yang digunakan ialah 10 tahun terakhir.

\section{Hasil}

Perawat pelaksana telah melakukan asuhan keperawatan pada tahap perencanaan/intervensi keperawatan dimana tujuannya berpusat pada pasien, dan hasil yang diperkirakan ditentukan dan intervensi keperawatan dipilih untuk mencapai tujuan (Potter \& Perry, 2005, p.180). Rencana keperawatan sebagai suatu dokumen tulisan tangan dalam menyelesaikan masalah, tujuan dan intervensi. Rencana keperawatan merupakan metode komunikasi tentang asuhan keperawatan kepada klien.

Perencanaan adalah proses pengambilan keputusan manajerial yang mencakup penelitian lingkungan, penggambaran sistem organisasi secara keseluruhan memperjelas visi, misi dan filosofi organisasi, memperkirakan sumber daya organisasi, mengidentifikasi dan memilih langkah-langkah tindakan, memperkirakan efektifitas tindakan dan menyiapkan karyawan untuk melaksanakannya (Gilles, 1994).

Perencanaan disini yaitu mengatur dan mengendalikan asuhan keperawatan, pengorganisasian disini dalam hal mengendalikan tenaga keperawatan, pengarahan dalam hal meningkatkan kolaburasi antar tim, sedangkan untuk pengawasan dalam hal supervisi kepada setiap anggota perawatan yang bekerja di ruangan tersebut.

Mutu asuhan keperawatan yang baik apabila semua tugas yang dilimpahkan dapat dijalankan dengan baik Tanggung jawab ketua tim dalam perencanaan, evaluasi, mengetahui kondisi pasien, menilai tingkat kebutuhan pasien, mengembangkan kemampuan anggota dan menyelengarakan konferensi.

Tahap perencanaan memberikan kesempatan kepada perawat, klien, keluarga dan orang terdekat klien untuk merumuskan rencana tindakan keperawatan guna mengatasi masalah yang dialami klien. Implementasi dari rencana asuhan keperawatan mengikuti komponen perencanaan dari proses keperawatan. Sedangkan di lingkungan perawatan kesehatan lainnya, implementasi mungkin dimulai secara langsung setelah pengkajian (Potter \& Perry, 2005).

\section{Pembahasan}

Pelayanan keperawatan merupakan bagian integral dari pelayanan kesehatan yang bisa menjadi tolak ukur keberhasilan dalam pencapaian tujuan suatu rumah sakit. Kualitas pelayanan keperawatan berjalan dengan baik apabila proses keperawatan yang dilaksanakan terstruktur dengan baik (Farlinda, 2011). Kualitas pelayanan yang baik akan meningkatkan kepuasan pasien dan keluarga demikian juga sebaliknya jika pasien dan keluarga tidak puas maka akan meninggalkan rumah sakit bila kualitas 
pelayanan buruk (Muhlisin, 2008). Kualitas pelayanan ditentukan oleh manajemen asuhan keperawatan.

Mutu asuhan keperawatan yang baik apabila semua tugas yang dilimpahkan dapat dijalankan dengan baik Tanggung jawab ketua tim dalam perencanaan, evaluasi, mengetahui kondisi pasien, menilai tingkat kebutuhan pasien, mengembangkan kemampuan anggota dan menyelengarakan konferensi. 5 unsur utama dalam penentuan pemilihan metode pemberian asuhan keperawatan (Tomey,Mariner 1996) yaitu :

1. Sesuai dengan visi dan misi institusi.

2. Dapat diterapkan proses keperawatan dalam asuhan keperawatan.

3. Efisien dan efektif penggunaan biaya.

4. Terpenuhinya kepuasan klien, keluarga dan masyarakat.

5. Kepuasan kinerja perawat.

Implementasi dari rencana asuhan keperawatan mengikuti komponen perencanaan dari proses keperawatan. Sedangkan di lingkungan perawatan kesehatan lainnya, implementasi mungkin dimulai secara langsung setelah pengkajian (Potter \& Perry, 2005).

Dokumentasi asuhan keperawatan menggunakan pendekatan proses keperawatan yang terdiri dari pengkajian, perumusan diagnosa, perencanaan, pelaksanaan, dan evaluasi sebagai metode ilmiah penyelesaian masalah keperawatan pada pasien untuk meningkatkan outcome pasien (Aziz, 2002). Dokumentasi keperawatan dalam bentuk dokumen asuhan keperawatan merupakan salah satu alat pembuktian atas perbuatan perawat selama menjalankan tugas pelayanan keperawatan. Sehingga dokumentasi asuhan keperawatan menjadi hal yang penting sebagai alat bukti tanggung jawab dan tanggung gugat dari perawat dalam menjalankan tugasnya.

Menurut Wirawan, Novitasari, Wijayanti, (2013) bahwa dokumentasi asuhan keperawatan dipengaruhi oleh motivasi perawat dan supervisi kepala ruang, sedangkan menurut Zakiyah (2012) pendokumentasian dipengaruhi oleh sikap dan tingkat pendidikan perawat. Sikap yang baik dan semakin tinggi tingkat pendidikan akan berpengaruh kepada pendokumentasian asuhan keperawatan yang semakin baik. Semakin baik dalam pengisian dokumentasi keperawatan akan membuat perencanaan keperawatan menjadi lebih baik dan kepuasan pasien meningkat. (AlAssaf,2009).

\section{Perencanaan}

(Planning).

Perencanaan adalah fungsi dasar dan pertama dalam manajemen (the first function of management). Semua fungsi manajemen tergantung dari perencanaan. Perencanaan adalah suatu proses berpikir atau proses mental untuk membuat keputusan dan peramalan (forecasting). Perencanaan harus berorientasi ke masa depan dan memastikan kemungkinan hasil yang diharapkan (Swansburg \& Swansburg, 1999). Dalam perencanaan, salah satu hal penting yang menjadi pusat perhatian adalah rencana pengaturan sumber daya manusia (SDM) dan sumber daya yang lain yang relevan. Perencanaan yang baikakan meningkatkan capaian tujuan dan pembiayaan yang efektif.

Perencanaan keperawatan yang
dibuat setelah perawat mampu
memformulasikan diagnosis keperawatan.
Perawat memilih metode khusus dan
memilih sekumpulan tindakan alternatif


untuk menolong pasien mempertahankan kesejahtraan yang optimal. Semua kegiatan keperawatan harus menggunakan sumbersumber yang tersedia melalui penetapan tujuan jangka panjang dan jangka pendek. Perencanaan disini yaitu mengatur dan mengendalikan asuhan keperawatan, pengorganisasian disini dalam hal mengendalikan tenaga keperawatan, pengarahan dalam hal meningkatkan kolaburasi antar tim, sedangkan untuk pengawasan dalam hal supervisi kepada setiap anggota perawatan yang bekerja di ruangan tersebut.

Setiap pasien yang memerlukan asuhan keperawatan perlu suatu perencanaan yang baik. Perencanaan adalah bagian dari fase pengorganisasian dalam proses keperawatan yang meliputi tujuan perawatan, penetapan pemecahan masalah, dan menentukan tujuan perencanaan untuk mengatasi masalah klien (Aziz, 2002). Suatu perencanaan yang kurang baik akan berakibat rendahnya mutu pelayanan keperawatan pada pasien sebagai akibat dari data yang kurang lengkap.

Tahap perencanaan memberikan kesempatan kepada perawat, klien, keluarga dan orang terdekat klien untuk merumuskan rencana tindakan keperawatan guna mengatasi masalah yang dialami klien. Perencanaan ini merupakan suatu petunjuk tertulis yang menggambarkan secara tepat rencana tindakan keperawatan yang dilakukan terhadap klien sesuai dengan kebutuhannya berdasarkan diagnosis keperawatan. Tahap perencanaan disebut sebagai inti atau pokok dari proses keperawatan sebab perencanaan merupakan keputusan awal yang memberi arah bagi tujuan yang ingin dicapai, hal yang akan dilakukan, termasuk bagaimana, kapan, dan siapa yang akan melakukan tindakan keperawatan. Penyusunan rencana tindakan keperawatan untuk klien, keluarga dan orang terdekat perlu dilibatkan secara maksimal (Asmadi, 2008).

Tahap perencanaan melibatkan serangkaian tahap dimana perawat dan pasien menyusun prioritas, menulis tujuan dan hasil yang diharapkan, dan menulis rencana tindakan guna menyelesaikan masalah klien. Jenis rencana keperawatan meliputi : intervensi mandiri, intervensi kerja sama (interdependensi) dan intervensi tergantung Intervensi mandiri melibatkan aspek-aspek praktek keperawatan profesional yang secara hukum dilakukan perawat dan tidak membutuhkan supervisi atau arahan dari profesi lain Aktual.

Perencanaan dalam manajemen keperawatan berdasarkan jangka waktunya dibagi menjadi 3 jenis, yaitu :

1) perencanaan jangka pendek, atau yang disebut sebagai perencanaan operasional adalah perencanaan yang dibuat untuk kegiatan dengan kurun waktu satu jam sampai dengan satu tahun.

2) jangka menengah, perencanaan yang dibuat untuk kegiatan dengan kurun waktu antara satu tahun sampai lima tahun (Marquis \& Huston, 1998).

3) jangka panjang, , atau sering disebut perencanaan strategis adalah perencanaan yang dibuat untuk kegiatan 3- 20 tahun (Swanburg, 1999).

Langkah - Langkah Perencanaan dalam Asuhan Keperawatan, yaitu :

1) Menentukan Prioritas Masalah 
Dalam menentukan perencanaan perlu disusun suatu sistematis untuk menentukan diagnosis

yang akan pertama kali diintervensi. Secara realistis, perawat tidak dapat mengatasi semua diagnosis keperawatan dan masalah kolaboratif yang terjadi kepada sebagian klien (individu), keluarga, dan masyarakat dengan mengidentifikasi prioritas diagnosis keperawatan dan masalah kolaboratif, perawat dapat memprioritaskan peralatan yang diperlukan.

2) Menyusun Kriteria Hasil atau Tujuan

Tujuan klien dan tujuan keperawatan merupakan standar atau ukuran yang digunakan untuk

mengevaluasi kemajuan klien atau keterampilan perawat. Kriteria hasil (outcome) untuk diagnosis keperawatan mewakili status kesehatan klien dapat diubah atau dipertahankan melalui rencana asuhan keperawatan yang mandiri, sehingga dapat dibedakan antara diagnosis keperawatan dan masalah kolaboratif.

3) Memilih rencana intervensi atau tindakan keperawatan

Rencana intervensi keperawatan adalah desain spesifik dari intervensi yang disusun untuk membantu klien dan mencapai kriteria hasil. Karakteristik Rencana Asuhan Keperawatan :

a. Konsisten dengan rencana intervensi keperawatan.

b. Berdasarkan prinsip - prinsip ilmiah (rasional).

c. Berdasarkan kondisi klien (individu).

d. Digunakan untuk menciptakan suatu situasi yang aman dan terapeutik.

e. Menciptakan suatu situasi pengajaran. f. Menggunakan sarana yang sesuai.

4) Melakukan pendokumentasian

Format rencana asuhan keperawatan membantu perawat untuk memproses data yang diperoleh selama tahap pangkajian dan penegakan diagnosis keperawatan. Ŕencana asuhan keperawatan ditulis dalam suatu bentuk yang bervariasi guna mempromosikan perawatan yang meliputi perawatan individu, perawatan yang berkelanjutan, sebagai media komunikasi, dan evaluasi keberhasipan asuhan keperawatan. Setelah melakukan pengkajian, perawat harus mulai untuk mendokumentasikan diagnosis aktual atau risiko, kriteria hasil, dan rencana intervensi.

\section{Penutupan}

Rencana keperawatan sebagai suatu dokumen tulisan tangan dalam menyelesaikan masalah, tujuan dan intervensi. Rencana keperawatan merupakan metode komunikasi tentang asuhan keperawatan kepada klien.

\section{Perencanaan adalah proses} pengambilan keputusan manajerial yang mencakup penelitian lingkungan, penggambaran sistem organisasi secara keseluruhan memperjelas visi, misi dan filosofi organisasi, memperkirakan sumber daya organisasi, mengidentifikasi dan memilih langkah-langkah tindakan, memperkirakan efektifitas tindakan dan menyiapkan karyawan untuk melaksanakannya (Gilles, 1994). Tahap perencanaan memberikan kesempatan kepada perawat, klien, keluarga dan orang terdekat klien untuk merumuskan rencana tindakan keperawatan guna mengatasi 
masalah yang dialami klien. Implementasi dari rencana asuhan keperawatan mengikuti komponen perencanaan dari proses keperawatan. Sedangkan di lingkungan perawatan kesehatan lainnya, implementasi mungkin dimulai secara langsung setelah pengkajian (Potter \& Perry, 2005).

Mutu asuhan keperawatan yang baik apabila semua tugas yang dilimpahkan dapat dijalankan dengan baik Tanggung jawab ketua tim dalam perencanaan, evaluasi, mengetahui kondisi pasien, menilai tingkat kebutuhan pasien, mengembangkan kemampuan anggota dan menyelengarakan konferensi.

\section{Daftar Pustaka}

Anggeria, E. Maria. (2018). Hubungan Supervisi dengan Pelaksanaan Asuhan Keperawatan. Jurnal Jumantik,3(2) : 7897.

Budiono, \& Pertami, S. B. (2016). Konsep Dasar Keperawatan.Jakarta: Bumi Medika.

Butar-Butar, J., \& Simamora, R. H. (2016).

Hubungan Mutu Pelayanan

Keperawatan dengan Tingkat Kepuasan

Pasien Rawat Inap di RSUD Pandan

Kabupaten Tapanuli Tengah. Jurnal

Ners Indonesia, 6(1), 50-63.

Hariyati, R. (2014). Perencanaan, pengembangan dan utilisasi tenaga keperwatan. Jakarta:Rajawali Pers.

Hidayah, N. (2014). Manajemen Model Asuhan Keperawatan Professional (MAKP) dalam Peningkatan Kepuasan Pasien di Rumah Sakit. Jurnal Kesehatan,7 (2).
Husnul Wirdah, Yusuf M. (2017).

Penerapan Asuhan Keperawatan oleh

Perawat Pelaksana di Rumah Sakit

Banda Aceh. Jurnal Keperawatan

Indonesia,2 (1) : 1-7.

Kasim, M., Abdurraouf, M. (2016).

Peningkatan Kualitas Pelayanan dan pendokumentasikan Asuhan

Keperawatan Dengan Metode TIM.

Nurseline Journal, 1 (1) : 62-72.

Mugianti S. (2016). Manajemen dan

Kepemimpinan Dalam Praktek

Keperawatan. Badan PPSDM

Kesehatan.

Octy R.R, Tatiana Siregar. (2019).

Hubungan Berpikir Kritis dengan

Kepedulian Perawat dalam

Melaksanakan Asuhan Keperawatan di

RSUD Kota Depok. Jurnal Kedokteran dan Kesehatan, 15 (2).

Simamora, R. H. (2005). Hubungan Persepsi

Perawat Pelaksana Terhadap Penerapan

Fungsi Pengorganisasian Yang

Dilakukan Oleh Kepala Ruangan

Dengan Kinerjanya Diruang Rawat Inap

RSUD Koja Jakarta Utara (Doctoral dissertation, Tesis FIK UI, Tidak dipublikasikan).

Yanti. R.I., Warsito, B.E. (2013). Hubungan

Karakteristik Perawat, Motivasi, dan Supervisi dengan Kualitas Dokumentasi Proses Asuhan Keperawatan. Jurnal Management Keperawatan,1 (2) : 107114.

Yuyun P, Tri, Putri W. (2016). FaktorFaktor Yang Berhubungan dengan Pendokumentasian Asuhan Keperawatan di Rumah Sakit Jiwa. Ners Jurnal Keperawatan,12 (2) : 131-142. 
